\title{
MENELUSURI RELIGIOSITAS MASYARAKAT
}

\author{
Yustinus Slamet Antono* \\ Program Studi Ilmu Filsafat, Fakultas Filsafat, Unika Santo Thomas \\ Email: yustinov_ant@yahoo.com
}

\begin{abstract}
Abstrak
Dilihat dari banyaknya suku bangsa yang ada di Indonesia, masyarakat Indonesia bisa digolongkan sebagai masyarakat majemuk. Dengan sendirinya pada masyarakat demikian bisa ditemukan berbagai aktivitas dalam kehidupan yang berhubungan dengan religiositas masyarakat yang bersangkutan. Selain itu dalam skala nasional, pemerintah Indonesia telah menetapkan pada tanggaltanggal tertentu sebagai hari libur. Di antara hari libur yang ditetapkan itu adalah hari-hari yang terkait dengan hari besar agama tertentu. Selain aktivitas hari-hari keagamaan dalam masyarakat bisa dijumpai berbagai perayaan yang sifatnya lokal, yaitu perayaan atau aktivitas yang terkait dengan adat-istiadat masyarakat yang bersangkutan. Perayaan yang bersifat tradisional itu sangat boleh jadi berhubungan dengan sistem kepercayaan masyarakat setempat. Artikel ini akan mengulas bagaimana fenomenologi ataupun pendekatan fenomenologis dimanfaatkan untuk menelusuri berbagai aktivitas (perayaan) masyarakat baik yang bersumber dari agama-agama maupun yang bersumber dari kepercayaan masyarakat setempat.
\end{abstract}

Kata-kata Kunci: Agama, religiositas, sakral, ritual.

\section{Implikasi Konseptual}

Ketika mendeskripsikan konsep kebudayaan, para ahli di bidangnya biasanya memiliki sudut padang dan pendekatan yang berbeda antara yang satu dengan yang lain. Akibatnya, dalam literatur-literatur yang berbicara tentang kebudayaan bisa ditemukan berbagai definisi kebudayaan dan pertangungjawaban ilmiahnya. Hal semacam itu juga berlaku ketika kita mencoba untuk mencari dan menemukan definisi

\footnotetext{
*Yustinus Slamet Antono, Doktor dalam bidang Ilmu Sosiologi; lulusan Universitas Indonesia, Jakarta; dosen tetap pada Fakultas Filsafat Unika St. Thomas, Sumatera Utara.
} 
agama (Betty R. Scharf, 2004: 34-36). Yang sering ditemukan kemudian adalah tolok ukur atau indikator-indikator apakah suatu sikap atau kepercayaan itu bisa dikategorikan sebagai agama atau tidak. Para ahli dalam bidang ilmu sosial juga memiliki sudut pandang dan tekanan yang berbeda-beda ketika mendeskripsikan agama. Mereka akan berusaha untuk tidak memasuki wilayah teologis yang memberikan evaluasi apakah suatu ajaran agama itu benar atau salah, melainkan berusaha masuk ke dalam wilayahnya sendiri yaitu implikasi sebuah kepercayaan atau agama dalam kehidupan sosial (Elizabeth K. Nottingham, 2002: ixxi).

Hingga dewasa ini perbincangan tentang agama masih sangat relevan untuk dibicarakan dalam kaitannya dengan bidang-bidang kehidupan yang lain. Persoalan-persoalan yang sering muncul dari definisi agama adalah adanya klaim bahwa agama yang paling benar adalah agama tertentu yang sebenarnya merupakan pembelaan dari pemilik agama yang bersangkutan dan dengan klaim itu kadang-kadang terjadi pemaksaan agar orang memeluk agama yang dianutnya. Klaimklaim sebagai yang paling benar semacam itu tidak jarang menimbulkan konflik horisontal baik konflik di antara umat beragama yang bersangkutan maupun antar agama yang lain. Klaim-klaim kebenaran seperti itu bisa berimbas pada keberadaan kepercayaan-kepercayaan tradisional yang sebenarnya telah menyatu dengan adat-istiadat masyarakat setempat dan dijadikan sebagai pedoman dalam kehidupan bersama. Sangat boleh jadi praktek-praktek yang terkait dengan kepercayaan tradisional itu secara sistematis dihilangkan oleh penganut agama yang mengklaim ajarannya sebagai yang paling benar. Sekalipun begitu, kepercayaan-kepercayaan tradisional yang diwariskan oleh generasi sebelumnya dan jauh lebih tua umurnya daripada agama yang mengklaim memiliki kebenaran itu masih tetap bertahan dan dipertahankan. Mengapa hal semacam itu bisa terjadi? Hal itu bisa terjadi karena kepercayaan atau sistem kepercayaan yang telah menyatu dengan adat-istiadat itu keberadaannya atau terbentuknya berkaitan langsung dengan lingkungan alam dan sosial dari masyarakat yang bersangkutan sehingga terdapat kemungkinan bahwa sistem kepercayaan tradisional itu 
langsung berkaitan dengan kehidupan praktis sehari-hari (Parsudi Suparlan, 1995: 3-22).

Jika definisi agama yang dipergunakan sebenarnya hanya terkait dengan agama yang resmi diakui pemerintah, maka kepercayaan atau sistem kepercayaan tradisional yang amat beragam itu tidak mendapatkan tempat yang cukup untuk diamati dan dipelajari. Sementara itu, hingga sekarang ini walaupun di Indonesia terdapat enam agama yang diakui secara resmi dan sebagian besar setiap penduduk memiliki identitas di antara keenam agama tersebut, dalam berbagai kesempatan dan kepentingan masih menghayati kepercayaan tradisionalnya karena memang terkait langsung dengan kehidupan praktis sehari-hari ataupun dimanfaatkan untuk menyelesaikan masalah-masalah yang tidak disediakan oleh agama yang dianutnya. Oleh karena itu banyaknya definisi agama yang dibuat oleh para ahli tidaklah mencukupi jika cakupannya hanya sempit saja. Atas dasar itu para ahli dalam bidang ilmu sosial berusaha untuk mendefinisikan agama seuniversal mungkin, artinya definisi agama tersebut bisa dikenakan atau berlaku pada baik agama resmi maupun agama-agama tradisional atau sistem kepercayaan tradisional. Definisi semacam itu tampak pada tulisan Emile Durkheim tentang agama (Emile Durkheim, 1965: 62).

\section{Religiositas}

Sebagai sebuah konsep, religiositas banyak digunakan untuk membicarakan hal-ikhwal yang terkait dengan agama atau praktek kehidupan beragama dalam suatu masyarakat. Dalam KBBI daring (online), religiositas diartikan sebagai pengabdian terhadap agama; kesalehan ${ }^{1}$. Sementara itu, religius diartikan sebagai bersifat religi; bersifat keagamaan; yang bersangkut paut dengan religi ${ }^{2}$. Religius merupakan kata sifat yang berasal dari kata religi. Religi dalam KBBI daring diartikan sebagai kepercayaan kepada Tuhan; kepercayaan akan adanya kekuatan adikodrati di atas manusia; kepercayaan (animisme,

\footnotetext{
${ }^{1}$ https://kbbi.kemdikbud.go.id/entri/religiositas

2 https://kbbi.kemdikbud.go.id/entri/religius
} 
dinamisme); agama $^{3}$. Ketiga istilah tersebut (religiositas, religius, religi) berkaitan dengan kehidupan beragama dan oleh karena itu berhubungan dengan the sacred things atau obyek sakral.

Dalam suatu negara di mana masyarakatnya merupakan masyarakat majemuk (Parsudi Suparlan, 1995: 7-10), konsep religiositas lebih fleksibel jika digunakan untuk menerangkan berbagai ekspresi yang terkait dengan kehidupan keberagamaan. Tidak sulit untuk menemukan suatu masyarakat yang pada suatu saat mempraktekkan apa yang dituntut oleh agama resmi dan pada saat yang lain mempraktekkan juga agama populer atau agama rakyat yang boleh jadi entitas keagamaan populer itu melekat dalam kebudayaannya yang dihayati dalam kehidupan seharihari. Jadi jika peneliti hendak melakukan kajian tentang semua ekspresi keagamaan suatu masyarakat istilah religiositas lebih mengena dibandingkan dengan istilah-istilah lainnya.

Memperhatikan dan mempertimbangkan berbagai teori tentang agama sebagaimana telah diuraikan pada bagian terdahulu, maka untuk keperluan studi lebih lanjut bisa dibuat definisi operasional. Untuk keperluan itu, religiositas bisa didefinisikan sebagai: seperangkat ide atau gagasan tentang yang sakral (the Sacred) dan tindakan-tindakan atau sikap-sikap yang menyertainya. Ide tentang yang sakral itulah yang dimaksudkan sebagai obyek sakral. Istilah "obyek" digunakan untuk menunjuk pada sesuatu yang berada di luar dirinya dalam pengertian yang luas yaitu berbagai konsep yang diperoleh sebagai akibat sosialisasi dari masyarakat atau orang-orang di sekitarnya. Jadi obyek sakral itu sudah ada sebelum individu dilahirkan dan akan menjadi miliknya jika individu tersebut menginternalisasikan. Sementara itu, "tindakantindakan atau sikap-sikap yang menyertainya" menunjuk pada ritual yang dilakukan sebagai implikasi pengakuan atas eksistensi obyek sakral tersebut. Berbagai perasaan yang timbul akibat pengalaman perjumpaan dengan obyek sakral tersebut diandaikan sudah tercakup melalui keterangan "tindakan-tindakan dan sikap-sikap yang menyertainya".

\footnotetext{
${ }^{3}$ https://kbbi.kemdikbud.go.id/entri/religi
} 
Pada tataran kongkrit terdapat hal-hal seperti berikut ini. Tidak semua yang disosialisasikan oleh masyarakat atau orang tua pada individu diinternalisasikan oleh individu yang bersangkutan. Sebaliknya, apa yang sudah diinternalisasikan bisa saja diabaikan setelah ia memperoleh suatu pemahaman baru tentang apa-apa saja yang telah diiternalisasikan. Sekalipun begitu, apa-apa saja yang sudah diinternalisasikan itu tetap tertinggal dalam ingatannya sebagai bagian dari stok pengetahuannya. Dalam menghadapi masalah-masalah kritis kehidupan, individu mungkin akan mengkombinasikan antara stok pengetahuan lama dan stok pengetahuannya yang baru. Ia mungkin juga akan menggunakan stok pengetahuan lama yang pernah ia miliki jika ternyata stok pengetahuan yang baru tidak bisa digunakan untuk mengatasi masalah-masalah kehidupan yang sedang dihadapi (Piter L. Berger, 1966: 15-37). Pada tingkat jemaat yang kebanyakan dikombinasikan adalah soal cara. Maksudnya demikian, pada religiusitas Jawa terdapat cara-cara yang cocok atau patut untuk memberi penghormatan pada pada apa saja yang perlu dihormati. Kepada orang yang lebih tua atau dituakan orang sepatutnya menunjukkan sikap hormat, yang antara lain diungkapkan dalam penggunaan bahasa Jawa halus. Contoh lain, menyembah dengan cara mengatupkan kedua tangan adalah cara yang dianggap paling cocok untuk memberi penghormatan. Cara menyembah seperti itu juga dilakukan ketika ia berhadapan dengan The Sacred dalam perayaan ekaristi. Dalam kasus itu orang bisa menunjukkan sikap hormatnya dengan cara berlutut, sebuah cara yang bukan berasal dari religiusitas Jawa. Pada level ritual, menyelenggarakan slametan adalah salah satu cara dalam religiusitas Jawa untuk menghormati leluhur. Orang Jawa yang juga memiliki religiositas Katolik ia bisa menempuh dua cara sekaligus, yaitu menyelenggarakan slametan tradisional dan juga menyelenggarakan perayaan ekaristi. Tetapi ia juga bisa hanya menyelenggarakan perayaan ekaristi saja. Jadi sebenarnya ekspresi religiositas bukan hanya bisa dilihat dari terselenggaranya ritual-ritual komunal dalam skala besar, tetapi juga tampak dalam sikap-sikap mungkin spontan ketika seseorang berhadapan dengan kejadian-kejadian lingkungan alam maupun lingkungan sosialnya. 


\section{Fenomena Keagamaan}

Di atas sudah dijelaskan bahwa istilah religiositas lebih menguntungkan digunakan dalam menelusuri kekayaan rohani bangsa Indonesia dibandingkan dengan menggunakan istilah agama karena konsep agama sering hanya diberlakukan untuk agama-agama besar yang diakui di Indonesia. Dalam realitasnya kekayaan rohani itu "tampak ke permukaan" dalam ritual-ritual yang terkait dengan siklus daur kehidupan pada setiap suku bangsa. Diterimanya agama-agama dari luar Indonesia oleh masyarakat memungkinkan religiositas asli hilang, sengaja dihilangkan, tetap dipertahankan atau berjalan berdampingan dengan agama barunya. Dalam ritual perkawinan misalnya, hal-hal yang bersifat adat mungkin tidak akan ditinggalkan sama sekali bahkan mereka wajib melakukannya sebab tindakan adat tersebut akan menentukan seseorang itu dianggap "manusia" atau tidak oleh anggota masyarakatnya. "Apa yang tampak ke permukaan" secara ringkas sering disebut sebagai fenomena. Pendalaman lebih lanjut terkait dengan apa yang tampak atau bisa diamati secara empiris digunakan istilah fenomenologi.

Dalam wacana akademis terutama dalam sosiologi dan antropologi konsep agama (religi) lebih banyak digunakan dibandingkan dengan konsep religiositas. Para ahli di bidang itu biasanya memberi argumentasi-argumentasi untuk sampai pada tahap penentuan definisi operasional tentang agama. Definisi agama yang mereka rumuskan biasanya memang berlaku universal, artinya agama apapun bisa dilihat dari sudut pandang itu. Sejauh mereka menggunakan berbagai gejala yang bisa diamati dalam masyarakat terkait dengan kehidupan "keagamannya" maka dalam arti tertentu para ahli tersebut telah menggunakan pendekatan fenomenologi. Itulah sebabnya terdapat bukubuku yang berjudul fenomenologi agama dengan berbagai keterangan tambahan sesuai dengan tekanan yang dibahas di dalamnya.

Fenomena keagamaan yang terdapat dalam kehidupan masyarakat menyediakan begitu banyak kemungkinan bagi para ahli untuk dijadikan sebagai bahan kajiannya. Mereka umumnya sengaja membatasi perbincangan tentang agama dalam koridor keilmuannya 
sehingga hasil karyanya bisa dibedakan antara disiplin ilmu yang satu dengan disiplin ilmu lainnya. Dengan kata lain, ilmuwan biasanya berbicara sesuai dengan kompetensinya terlebih lagi jika pokok yang dibicarakan itu bersinggungan dengan agama. Seorang sosiolog atau antropolog misalnya, ia tidak akan memberikan penilaian apakah praktek ajaran agama tertentu itu benar atau salah. Urusan benar atau tidaknya praktek keagamaan seseorang atau sekelompok orang lebih menjadi wilayah perbincangan para teolog. Sosiolog akan berbicara mengenai praktek keagamaan seseorang atau sekelompok orang sejauh praktek keagamaan tersebut berpengaruh atau tidak berpengaruh pada kehidupan masyarakat. Hal yang serupa terjadi jika para sosiolog berbicara mengenai kesehatan. Menentukan apakah seseorang itu menderita sakit tertentu atau tidak, bukan menjadi wilayahnya. Sosiolog akan mengkaji bagaimana penyakit yang dialami seseorang itu berpengaruh pada kehidupan sosial pasien. Dalam lingkup yang lebih luas, mungkin sosiolog akan mengkaji bagaimana kebiasaan kearifan lokal masyarakat dalam menanggulangi suatu penyakit tertentu (Betty R. Scharf, 2004: 13).

Dalam dunia akademis, biasanya terdapat buku-buku sebagai hasil studi yang sangat serius mengenai tokoh-tokoh yang sangat mempengaruhi berkembangnya salah satu atau beberapa bidang ilmu. Dalam buku tersebut biasanya terdapat semacam daftar inventarisir tokoh-tokoh berpengaruh tersebut lalu dikelompokkan berdasarkan kriteria-kriteria tertentu. Tidak jarang penulis buku tersebut secara terang-terangan menunjukkan keberpihakannya pada salah satu tokoh karena memiliki berbagai kesamaan dalam melihat fenomena yang dilihatnya. Sebaliknya, terdapat juga penulis buku yang juga sangat terang-terangan menunjukkan kekurangan atau kelemahan teori yang digunakan oleh penulis-penulis sebelumnya dan dari situ ia menawarkan metode, cara atau apapun istilahnya yang dirasa paling tepat untuk dijadikan sebagai pisau analisis terhadap suatu fenomena keagamaan atau fenomena lain yang terjadi dalam masyarakat (Betty R. Scharf, 2004: 49). 
James L. Cox (2006) bisa dijadikan sebagai salah satu contoh penulis buku yang sejak pada bagian awal menentukan posisi kajiannya di belantara kajian-kajian keagamaan sejenis. Ia berusaha menekankan kekhasan fenomenologi agama dibandingkan stusi-studi lain yang di dalamnya menjadikan agama sebagai obyek formalnya. Bagi James L. Cox, kekhasan itu penting untuk ditunjukkan mengingat tokoh-tokoh pemikir besar sangat berpengaruh dalam perkembangan berbagai ilmu pengetahuan, termasuk ilmu-ilmu sosial. Sebagai implikasinya adalah terdapat kemungkinan krisis identitas suatu ilmu ketika ilmu tersebut membahas bidang kajian yang sama. Pada awal bukunya ia mengatakan:

This book is born from a growing conviction, confirmed by my discussions with colleagues and supported by teaching in undergraduate and postgraduate courses, that religious studies, as a field midway between theology and the social and cultural sciences, suffers from a severe crisis of identity. In my view, this has resulted, at least in part, from the central role phenomenology of religions has played historically in the development of the academic study of religions (James L. Cox 2006: vii).

James L. Cox menjelaskan bahwa bahwa perkembangan studi agama-agama (the development of the academic study of religions) telah mempengaruhi perkembangan ilmu-ilmu lain (fenomenologi dan teologi). Secara tidak langsung ia menempatkan fenomenologi (agama) berada dalam rumpun studi akademis agama-agama. Dalam buku yang berjudul A Guide to the Phenomenology of Religion Key Figures, Formative Influences and Subsequent Debates itu ia memberikan penjelasan ruang lingkup fenomenologi dalam studi agama-agama.

Menyinggung tokoh-tokoh yang berpengaruh dalam studi agamaagama tersebut, mengikuti pendapat Daniel Pals dalam bukunya Seven Theories of Religions (1996) James L. Cox menyetujui bahwa terdapat tujuh tokoh yang dipandang berpengaruh secara teoritis dalam studi agama-agama. Mereka adalah E. B. Tylor dan James Frazer, Sigmund Freud, Emile Durkheim, Karl Marx, Mircea Eliade. E. E. Evans-Pritchard 
dan Clifford Geertz (James L. Cox 2006: 2-3). E. B. Tylor dan James Frazer dianggap sebagai satu kesatuan karena memiliki ide yang sama. Selanjutnya James L. Cox berpendapat bahwa tidak seorangpun dari nama-nama yang disebutkan tadi yang mengelompokkan dirinya fenomenolog. Akan tetapi James L. Cox berpendapat bahwa Mircea Eliade termasuk seorang fenomenolog, setidak-tidaknya dalam bukunya sendiri. Sebagian dari mereka lebih digolongkan sebagai antropolog kecuali Sigmund Freud yang mengembangkan teori Oedipus, Karl Marx berbicara tentang agama dalam konteks konstruksi ideologi sosial.

Sub judul pada bagian ini adalah fenomena keagaamaan. Jika diletakkan dalam konteks perbincangan mendalam tentang fenomenologi sebagai ilmu pengetahuan, terutama cakupan pembicaraannya tampaklah bahwa dari keterangan yang sudah dipaparkan bukan merupakan fenomenologi itu sendiri. Keterangan dalam sub judul pada bagian ini di satu pihak hendak mengatakan bahwa terdapat berbagai hal yang bisa diamati terkait dengan agama-agama dalam kehidupan kongkrit masyarakat baik pada masa lalu maupun pada masa kini.

Agama dan ekspresinya dalam kehidupan sehari-hari bisa dilihat dari berbagai sudut pandang ilmu. Dalam rangka etnografi, agama biasanya ditempatkan sebagai salah satu unsur kebudayaan. Unsur-unsur kebudayaan itu meliputi: nama suku bangsa, lokasi - lingkungan alam demografi, asal-usul dan sejarah, bahasa, sistem teknologi, sistem mata pencarian, sistem organisasi sosial, sistem pengetahuan, sistem kesenian, agama dan sistem religi (Koentjaraningrat, 1998: 6). Antropologi memiliki tradisi mendeskripsikan fenomena sosial secara holistis. Melalui cara itu fenomena sosial dianggap bisa dilihat secara utuh dan bisa dicari hubungan antara unsur yang satu dengan lainnya. Banyak sedikitnya informasi yang bisa diperoleh dari unsur-unsur kebudayaan atau fenomena sosial tersebut tergantung tekanan atau fokus pembicaraan para antropolog atau etnolog. 


\section{Relevansi}

Apakah menggali kembali religiositas tradisional masih relevan pada masa sekarang ini di Indonesia? Mengkaji kembali religiositas atau apapun yang terkandung di dalamnya masih sangat relevan dan akan tetap relevan dilakukan di Indonesia. Fakta historis menunjukkan bahwa bangsa Indonesia menjadi seperti sekarang ini ada, tidak lepas dari usaha asa lalu untuk menyatukan suku-suku yang berbeda-beda menjadi sebuah negara. Usaha semacam itu juga dilakukan pada masa kerajaan Majapahit dengan semboyannya yang terkenal yaitu bhinneka tunggal ika. Semboyan itu juga dipakai oleh negara Indonesia hingga sekarang ini. Faktanya, pada masa kerajaan Majapahit, semboyan semacam itu mampu dan efektif menyatukan perbedaan berbagai suku bangsa yang ada di wilayah Nusantara. Sekalipun pada masa itu terdapat dua agama dominan yaitu agama Budha dan Hindu, namun praktek keagamaan pada masa itu tidak menyebabkan rakyat yang berada pada kekuasaan kerajaan Majapahit terpecah dan para pemeluknya saling menghormati satu sama lain. Dengan kata lain semboyan bhinneka tunggal ika berkontribusi dalam menciptakan suasana harmoni dalam kehidupan masyarakat. Harmoni dalam kehidupan sosial itu tidak mungkin terjadi kalau pada masing-masing masyarakat yang tergabung dalam suatu kesatuan tidak memiliki sama sekali unsur-unsur harmoni dalam pranata kehidupannya.

Setiap negara pastilah berusaha mempertahankan baik wilayah maupun ideologi yang membuat masyarakatnya untuk tetap bersatu. Usaha sekecil apapun yang bermaksud mengganti ideologi akan diatasi. Istilah-istilah ekstrim kiri dan ekstrim kanan yang pernah digunakan dalam konteks pembicaraan persatuan Indonesia mengacu pada gerakan yang dasarnya adalah agama (kanan) dan komunisme (kiri). Gerakangerakan tersebut memang memiliki potensi untuk meruntuhkan persatuan Indonesia karena realitas kebhinnekaan masyarakat tidak mendapatkan tempat yang semestinya. Pada saat suatu generasi terjerumus ke dalam salah satu ekstrim, maka sangat perlulah melihat kembali mekanisme generasi terdahulu dalam upaya memelihara kebhinnekaan itu tetap terjaga. Salah satu cara yang bisa ditempuh adalah dengan menggali dan merevitalisasi nilai-nilai yang pernah dianut oleh generasi terdahulu itu. 
Apakah nilai-nilai terdahulu berhubungan dengan religiositas? Jawabannya adalah berhubungan sebab religiositas itu menyatu dengan berbagai aktivitas sehari-hari maupun yang tampak dalam adat-istiadat. Menelusuri kembali religiositas tradisional dan mendeskripsikannya secara akademis tidaklah pernah sia-sia karena bisa digunakan untuk merefleksikan kondisi yang sedang dialami dan juga bisa digunakan untuk peninggalan yang pada masa mendatang akan digunakan oleh generasi penerus sesudah kita.

$===0000===$ 


\section{DAFTAR PUSTAKA}

Berger, Peter L. and Luckmann, The Social Construction of Reality, Garden City: Doubleday \&Company, Inc., 1966.

Cox James L., A Guide to the Phenomenology of Religion Key Figures, Formative Influences and Subsequent Debates, London and New York: T\&T Clark International a Continuum Imprint, 2006.

Durkheim, Emile, The Elementary Forms of the Religious Life, New York: The Free Press, 1965.

Koentjaraningrat, Pengantar Antropologi Pokok-Pokok Etnografi II, Jakarta: Rineka Cipta, 1998.

Nottingham, Elizabeth K., Agama dan Masyarakat suatu Pengantar Sosiologi Agama, Jakarta: PT.RajaGrafindo Persada, 2002.

O'dea, Thomas F., Sosiologi Agama suatu Pengenalan Awal, Jakarta: Rajawali, 1987.

Scharf, Betty R., Sosiologi Agama, Jakarta: Prenada Media, 2004. Terj. Machnun Husein. M.Ag. 